\section{Morphology of a Small DNA Virus ${ }^{1}$}

Moore (1) recently reported on the biologic and immunologic characteristics of several viruses apparently belonging to a group, containing two immunologically distinct strains designated $\mathrm{H}-1$ and $\mathrm{H}-3$. Viruses of this group have been isolated from rats and from human tumors transplanted in conditioned rats (2-5). Toolan has reported that similar viruses have been isolated in hamsters from tissues of patients with neoplastic disease (6) and from normal human fetuses $(7)$. These viruses produce intranuclear inclusions containing DNA $(8-10)$, and unpublished work by Barclay has been cited $(6)$ in which infectious DNA was extracted from a transplanted tumor infected with $\mathrm{H}-1$ virus. Similarities have been noted between polyoma virus and various members of the group in question $(1,2,8,9)$; although these viruses have not been shown to be oncogenic, it has been suggested that they might be papova viruses (11). It was with this possibility in mind that the morphology of one of the viruses was examined.

Virus X14, isolated in our laboratory from mammary tissue of an X-irradiated Sprague-Dawley rat (4), was identified by comparison with a strain of $\mathrm{H}-1$ virus and Kilham's rat virus (RV), an $\mathrm{H}-3$ strain. ${ }^{2}$ Virus X14 was like the $\mathrm{H}-1$ virus and RV in that: it replicated in cultures of rat or hamster embryo cells and produced overt cytopathology only in rat cells; it did not produce cytopathology and could not be serially propagated in cultures of mouse, chicken, or human embryo cells; it produced a fatal infection in newborn hamsters and rats. Like RV, X14 agglutinated guinea pig and rat, but not human (type "O") erythrocytes. The $\mathrm{H}-1$ virus agglutinated guinea pig and human, but not rat, erythrocytes. In tests performed as described by Kilham and Olivier (2), hemagglutination of guinea

\footnotetext{
${ }^{1}$ This work was supported by United States Public Health Service grant CA 04571.

${ }^{2}$ The prototype viruses and typing sera were kindly supplied by Dr. Alice E. Moore of the Sloan-Kettering Institute for Cancer Research, New York.
}

pig erythrocytes by either $\mathrm{X} 14$ virus or $\mathrm{RV}$ was inhibited by $\mathrm{H}-3$ typing serum at a dilution of $1: 1280$ and by $\mathrm{H}-1$ typing serum at $1: 80$. The same $\mathrm{H}-1$ typing serum at a dilution of $1: 1280$ inhibited hemagglutination by $\mathrm{H}-1$ virus. Infection of rats with X14 virus yielded antisera which at a dilution of $1: 640$ inhibited hemagglutination by either X14 virus or RV, but at a dilution of $1: 20$ did not inhibit $H-1$ virus. From these observations it was concluded that X14 virus was similar to RV and of the H-3 serotype. The replication of X14 virus was inhibited by 5 -fluoro- 2 -deoxyuridine (12), and inhibition of replication by this compound has been considered evidence that a virus contains DNA (13, 14).

Virus was propagated and assayed in monolayer secondary cultures of rat embryo cells (2). Pools of virus were prepared from infected cultures in which all cells had rounded and detached from the glass. Cells and medium from these cultures were frozen, thawed, and centrifuged at 1000 rpm for 10 minutes in an International no. 1 centrifuge. The resulting supernatant fluid was stored at $-60^{\circ} \mathrm{C}$. Similarly prepared extracts from uninfected cultures were passaged in parallel with the virus and were used to inoculate normal cultures for the production of control pools. Virus pools contained from $10^{7.0}$ to $10^{9.0}$ TCID $_{50} / \mathrm{ml}$ and agglutinated guinea pig erythrocytes at dilutions of approximately $1: 4000$.

As shown in Table 1 , when an X14 virus pool was incubated for 1 hour at $20^{\circ}$ with $0.4 \%(\mathrm{v} / \mathrm{v})$ guinea pig erythrocytes (GPE) and the cells were then sedimented by centrifugation, both the infectivity $\left(\mathrm{TCID}_{50}\right.$ ) and the hemagglutinating activity (HA) of the supernatant fluid were less than those of the original pool. When this procedure was repeated serially, each time using supernatant fluid from the previous adsorption and fresh GPE, the infectivity and $\mathrm{HA}$ decreased in parallel; 80 to $90 \%$ of both activities were removed with each adsorption. Infectivity and $\mathrm{HA}$ were both eluted from GPE by incubation at $37^{\circ}$ for 
TABLE 1

Adsorption to and Elution from Guinea Pig Erythrocytes of Infectivity (TCID 50 ) and Hemagglutinin (HA) from Fluid of Tissue Cultures INFECTED WITH X14 VIRUS

\begin{tabular}{lccc}
\hline \multicolumn{1}{c}{ Sample } & $\begin{array}{c}\mathrm{TClD}_{50} \\
\left(\log _{10} / \mathrm{ml}\right)\end{array}$ & $\begin{array}{c}\mathrm{HA} \\
\left(\log _{10} \text { units } / \mathrm{ml}\right)\end{array}$ & $\begin{array}{c}\mathrm{TCID}_{50}: \mathrm{HA} \\
\left(\log _{10}\right)\end{array}$ \\
\hline Original & 7.3 & 3.8 & 3.5 \\
$\begin{array}{l}\text { Supernatant fluid after adsorption for 1 hour } \\
\text { at } 20^{\circ} \mathrm{C}\end{array}$ & 6.3 & 3.0 & 3.3 \\
$\begin{array}{l}\text { Eluate after RDE treatment for } 1 \text { hour at } \\
37^{\circ} \mathrm{C}\end{array}$ & 6.8 & 3.5 & 3.3 \\
\hline
\end{tabular}

1 hour with receptor destroying enzyme $(\mathrm{RDE}),{ }^{3} 40$ units $/ \mathrm{ml}$ in acetate buffer $\mathrm{pH}$ 5.5 containing $0.01 M \mathrm{CaCl}_{2}$. The $0.2 \log _{10}$ range of the $\mathrm{TCID}_{50}: \mathrm{HA}$ ratios in Table 1 was considered to be within the limits of error of the assays used. The fact that the $\mathrm{TCID}_{50}: \mathrm{HA}$ ratio remained essentially constant in the three samples tested suggested that the virus per se adsorbed to the erythrocytes and produced hemagglutination.

It was reasoned that if $\mathrm{X} 14$ virus adsorbed to erythrocytes, then virus relatively free of debris might be identified on the surface of these cells by electron microscopy. Accordingly $2 \mathrm{ml}$ of virus pool was mixed with $1 \mathrm{ml}$ of $0.4 \%$ GPE in phosphate-buffered saline at $\mathrm{pH}$ 7.0. After incubation for 2 hours the cells were sedimented by centrifugation, washed, and resuspended in buffered saline. The suspension was dialyzed against $10 \%$ neutral formalin, and the ghosts were washed and suspended in distilled water as described by Ishida et al (16). A drop of suspension was placed on a grid coated with a carbon film and mixed with a drop of $2 \%$ phosphotungstic acid solution at pH 7.4. Excess fluid was removed, and the remaining mixture was allowed to dry in air. Specimens were examined in an RCA EMU 2 A electron microscope without an objective aperture. Size calculations were made after

\footnotetext{
${ }^{3}$ RDE prepared from Vibrio cholerae, was obtained from Microbiological Associates and assayed according to the procedure of Burnet and Stone (15).
}

calibration with a Fullam diffraction grating replica (2160 lines $/ \mathrm{mm}$ ).

The identity of the virus and those particles to be described is supported by the following observations: (1) The particles were seen on erythrocytes incubated with each of several different pools of the virus. (2) They were not observed on cells incubated with corresponding control pools. (3) They were not seen on cells from which infectivity and HA had been eluted with RDE.

As Fig. 1 shows, the surface of ghosts derived from GPE that had been incubated with virus showed large numbers of particles about $22 \mathrm{~m} \mu$ in diameter. Both "full" (Fig. 1A and B) and "empty" (Fig. 1C) forms were present, and although the conditions for negative staining were constant, the proportion of particles penetrated by the stain varied from one virus pool to another. Measurement of 50 "full" forms revealed diameters ranging from 18 to $24 \mathrm{~m} \mu$ with a mode of $22 \mathrm{~m} \mu$. The photographic enlargements presented in Fig. 1AC suggest that the particles possess morphologic substructure, the nature of which will require further study.

To support the observation that there were both "full" and "empty" forms of the virus, an equilibrium density gradient was prepared by mixing 2 parts of virus pool with 1 part saturated $\left(20^{\circ}\right) \mathrm{CsCl}$ solution. After centrifugation for 48 hours at 39,000 rpm in an SW39 head of a Spinco model L centrifuge, the bottom of the tube was punctured and fractions of 4 drops each 


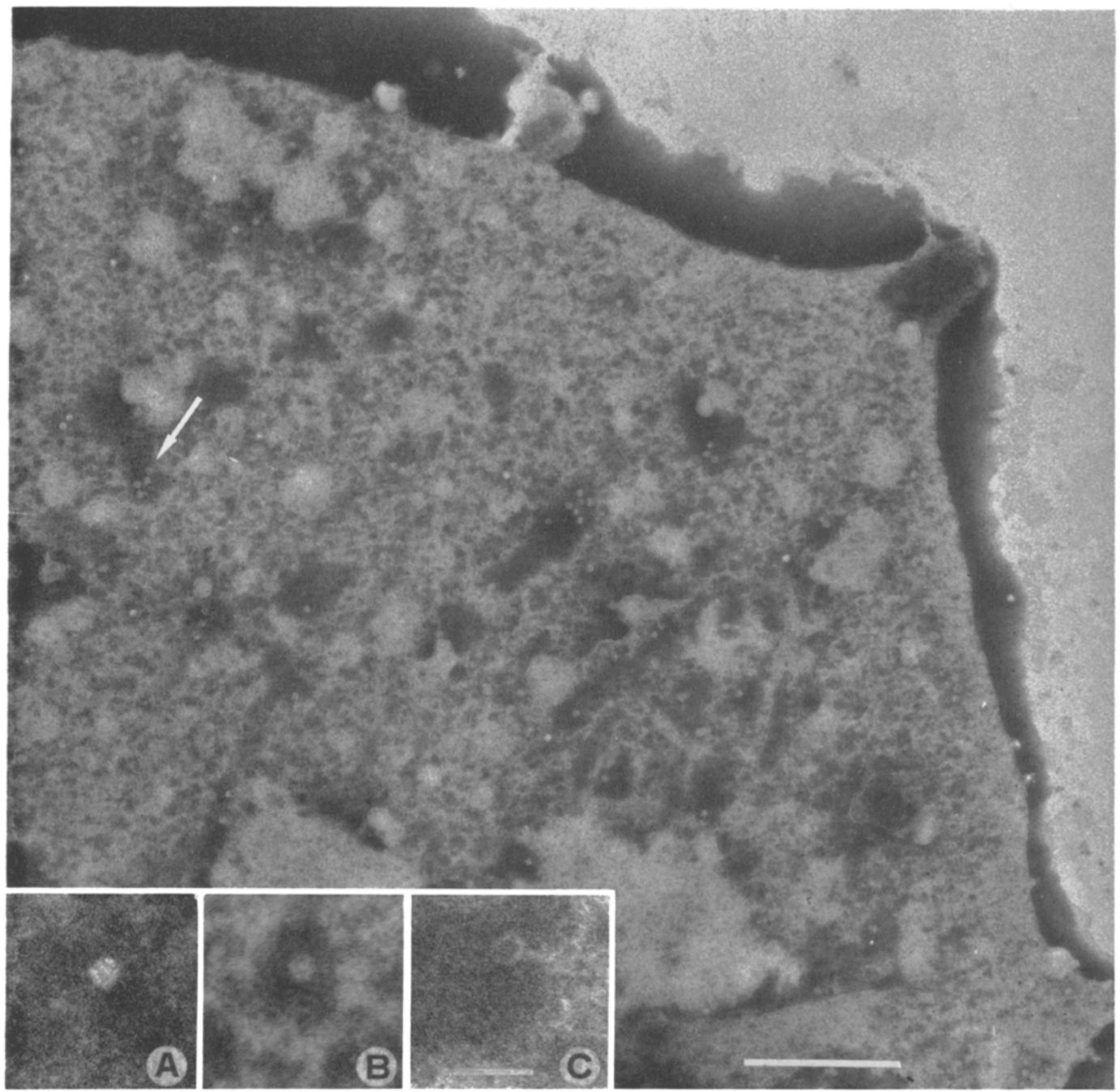

FIG. 1. X14 virus adsorbed to a guinea pig erythrocyte ghost and negatively stained with phosphotungstic acid. Arrow indicates a group of 4 particles about $22 \mathrm{~m} \mu$ in diameter. In the main figure the scale represents $500 \mathrm{~m} \mu$. That for the insets represents $50 \mathrm{~m} \mu$.

were collected. The density of each fraction was determined by weighing $50-\mu l$ aliquots in micropipettes. The distribution of infectivity and $\mathrm{HA}$ in a density gradient is shown in Fig. 2, where titers are expressed as percentages of the maximum titer obtained. The maximum and minimum titers for HA were 19,200 and 10 units $/ \mathrm{ml}$, respectively, and for infectivity the values were $10^{6.7}$ and $10^{2.6}$ TCID $_{50} / \mathrm{ml}$. Peaks of HA occurred at measured densities near 1.40 and $1.31 \mathrm{~g} / \mathrm{ml}$. The peak of
HA that occurred in the denser region of the gradient yielded the majority of the infectivity added to the gradient, and samples from this region had $\mathrm{TCID}_{50}$ : $\mathrm{HA}$ ratios of approximately $10^{4.0}$. The bimodal distribution of the HA of this virus is reminiscent of that seen with polyoma virus, where peaks from the denser and less dense regions of a gradient contain, respectively, "full" and "empty" particles when examined by the negative stain technique and electron microscopy (17). Also, the dis- 


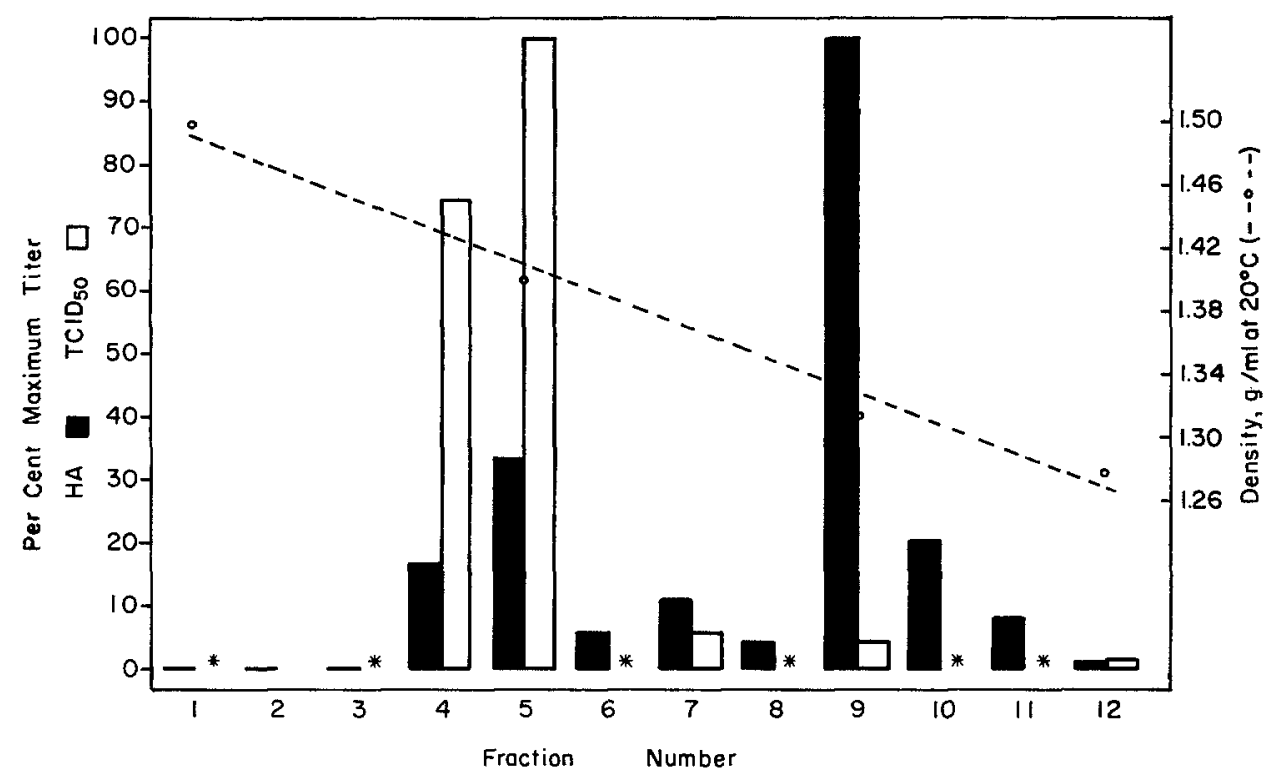

Fra. 2. The distribution of infectivity and hemagglutinating activity of X14 virus in a $\mathrm{CsCl}$ density gradient. Asterisks indicate $\mathrm{TCID}_{50}$ not determined for these fractions.

tribution of infectivity and $\mathrm{HA}$ of $\mathrm{X} 14$ virus in the density gradient suggests that both "full" and "empty" particles hemagglutinate but only the "full" particles are infectious.

Preliminary observations on several viruses of the $\mathrm{H}-3$ serotype, as well as an $\mathrm{H}-1$ strain, indicate that they are all morphologically similar to virus X14. Chandra and Toolan (18) have described particles $12-15 \mathrm{~m} \mu$ in diameter in cytoplasmic vacuoles of macrophages from hamsters infected with $\mathrm{H}-1$ virus. From the spacing of these particles it was concluded that they were nucleoids of a virus measuring $30 \mathrm{~m} \mu$ in diameter. Allowing for differences in technique, it is possible that the particles described were in fact virus particles of the type seen in the present study. ${ }^{4}$

The data presented indicate that X14 virus is morphologically quite distinct from

${ }^{*}$ While this communication was in preparation, A. J. Dalton, L. Kilham, and R. F. Zeigel [Virology 20, 391 (1963)] reported that the size, shape, and distribution of Kilham's rat virus (an $\mathrm{H}-3$ strain), as observed in thin sections of infected hamster cells, were similar to those described for H-1 virus by Chandra and Toolan (18). members of the papova group. Rather, the size, shape, and buoyant density of X14 are similar to those of $\phi \mathrm{X} 174(19,20)$ and related bacteriophages.

Note added in proof. Toolan, H. W., et al [Virology 22, 286 (1964)] examined by negative stain technique preparations containing $\mathrm{H}-1$ virus and reported visualizing particles which were similar to those described in the present report and which measured 24 to 25 $\mathrm{m} \mu$ in diameter.

\section{REFERENCES}

1. Moore, A. E., Virology 18, 182-191 (1962).

2. Kinham, L., and Olivier, L. J., Virology 7, 428-437 (1959).

3. Lum, G. S., and Schremer, A. W., Bacteriol. Proc., p. 134, Abstract V20 (1962).

4. Payne, F. E., Shellabarger, C. J., and Schmidt, R. W., Proc. Am. Assoc. Cancer Res. 4, 51, Abstract 201 (1963).

5. Toolan, H. W., Dalldorf, G., Barclay, M., Chandra, S., and Moore, A. E., Proc. Natl. Acad. Sci. U.S. 46, 1256-1258 (1960).

6. Toolan, H. W., Bull. N.Y. Acad. Med. 37, 305-310 (1961).

7. Toolan, H. W., Buttue, G. A. H., and Kay, H. E. M., Proc. Am. Assoc. Cancer Res. 3, 368, Abstract 278 (1962).

8. Dawe, C. J., LaW, L. W., Morgan, W. D., and 
Shaw, M. G., Federation Proc. 2l, 5-14 (1962).

9. Rabsòn, A. S., Kilham, L., and Kirschstein, R. L., J. Natl. Cancer Inst. 27, 1217-1223 (1961).

10. Hampton, E. G., Federation Proc. 22, p. 557, Abstract 2372 (1963).

11. Melnick, J. L., Science 135, 1128-1130 (1962.)

12. Cochran, K. W., and Payne, F. E., Proc. Soc. Exptl. Biol. Med. 115, 471-474 (1963)

13. Salzman, N. P., Shatkin, A. J., Sebring, E. D., and Munyon, W., Cold Spring Harbor Symp. Quant. Biol. 27, 237-243 (1962).

14. Committee on Enteroviruses, Virology 16, 501504 (1962).

15. Burnet, F. M., and Stone, J. D., Australian J. Exptl. Biol. Med. Sci. 25, 227-233 (1947).

16. Ishida, N., Amano, Y., and Krkawa, T., Virology 16, 498-501 (1962).

17. Abet, P., and Crawford, L. V., Virology 1.9, 470-474 (1963).

18. Chandra, S., and Toolan, H. W., J. Natl. Cancer Inst. 27, 1405-1450 (1961).

19. Sinsheimer, R. L., J. Mol. Biol. 1, 37-42 (1959).

20. Tromans, W. J., and Horne, R. W., Virology 15, 1-7 (1961).

Francis E. Payne

Theodore F. Beals

Robert E. Preston

Virus Laboratory and Department of Epidemiology

School of Public Health

University of Michigan

Ann Arbor, Michigan

Accepted February 17, 1964

\section{Decomposition of T6 Bacteriophage in Alkaline Solutions ${ }^{1}$}

When T-even bacteriophages are treated with acidic glycine buffer ( $\mathrm{pH} \mathrm{2}$ ), their tail sheaths contract and the particles disintegrate into their component parts. After neutralization and treatment with DNase, trypsin, and chymotrypsin, the parts can be partially purified by differential centrifugation (1). Examination of the isolated contracted sheaths in the electron microscope has revealed interesting details of their structures (2).

We have had occasion to observe the

${ }^{1}$ This work was supported in part by grants GB 250 and GB 982 from the National Science Foundation, and by grant CA 06927 from the National Institutes of Health. effects of brief treatment of $\mathrm{T} 6$ bacteriophage with mildly alkaline solutions which, instead of inducing contraction of the tail sheaths, frequently causes these structures to relax and induces the elements to separate from each other and from the hollow needle that runs through the center of the tail.

To a purified suspension of T6 in phosphate buffer ( $\mathrm{pH}$ 7.0) containing $10^{12}$ particles/ml (kindly supplied by Dr. E. Weiler and Miss Elsa P. Wright) were added four parts of $5 \%$ sodium bicarbonate to yield a final $\mathrm{pH}$ of 9.6 . After $30 \mathrm{~min}$ utes' incubation at $37.5^{\circ} \mathrm{C}$ the preparation was placed on a Formvar and carboncoated electron microscope grid. The grid was washed repeatedly in distilled water to remove the sodium bicarbonate, after which a droplet of $4 \%$ sodium silicotungstate ( $\mathrm{pH}$ 7.0) was mixed with the contents of the grid. The excess liquid was then removed with filter paper and the specimen quickly placed in the high vacuum of a Siemens Elmiskop I before the residual liquid had had an opportunity to dry in the air of the room (B).

Two kinds of previously seen phage particles were observed (Fig. 1): (a) "normal" particles with extended sheaths; and (b) "triggered" particles whose sheaths had contracted with their base plates attached to expose the bare tips of the needles. In the untreated controls, more than $95 \%$ of the particles had extended sheaths and only a few of the particles had been "triggered." However, after alkaline treatment many unusual particles were seen. In many of these, the sheaths had relaxed to form loose helical structures with base plates attached to the tips of the needles (Figs. 2 and 3 ). The linkage between base plate and sheath thus seems to be more sensitive to high $\mathrm{pH}$ than the linkage between base plate and needle. Disintegration of the sheaths seemed to start near the base plates and to progress toward the heads until particles like that in Fig. 4 were formed. These particles lacked contractile sheaths, and the base plates attached to the tips of the needles lacked well defined tail fibers. On the other hand, some sheaths contracted in alkaline 